\title{
Chapter 6 \\ R.J. Rummel, Nuclear Superiority, and the Limits of Détente
}

\author{
Matthew Kroenig and Bardia Rahmani
}

\subsection{Introduction}

Amid the intense security competition of the Cold War, the decade-long détente between the United States and Soviet Union stands out to many as a moment of pragmatic cooperation among rivals. The 1970s saw, among other developments, the adoption of arms control treaties such as SALT I and II, scientific collaboration between astronauts and cosmonauts, and the expanding of trade ties between Washington and Moscow. Bookended by the crises of the 1960s and the proxy wars of the 1980s, détente is the chapter of the Cold War in which peaceful coexistence seemed closest at hand. 'Détente is peace', wrote political scientist R.J. Rummel, 'Who in his right mind could speak out against peace?' (Rummel, 1976: 22).

In Peace Endangered: The Reality of Détente (1976), Rummel does just that. Tipping his hat to its intuitive appeal, Rummel nonetheless dismisses détente as faith, not sound policy. By conflating arms control and cooperative interaction with a durable peace, détente, in his view, weakened the West relative to the USSR and, in so doing, made war more, not less, likely. Détente, Rummel argues, is a road paved with good intentions and bad assumptions. And it is a road that forks off in one of two directions: nuclear war or unconditional Western surrender. 'This is the only choice', Rummel writes, 'unless we understand the dilemma and act to avoid it' (Rummel, 1976: 19).

Nearly forty years later, it might be tempting for us to dismiss Rummel's arguments as analysis distorted by Cold War paranoia. After all, history has proven Rummel wrong on many counts: America did not surrender to the Soviet Union;

Matthew Kroenig, b. 1977, Ph.D. in political science (University of California at Berkeley, 2007) is an Associate Professor in the Department of Government and School of Foreign Service at Georgetown University; Email: matthew.kroenig@georgetown.edu.

Bardia Rahmani, b. 1993, is an honors student in the School of Foreign Service at Georgetown University; Email: brahmani12@gmail.com. 
Moscow was neither resistant to the logic of mutual assured destruction nor as reckless as Rummel feared; and there is now substantial evidence that cooperative transactions can, in fact, lay the groundwork for peace among nations.

Nevertheless, it would be a mistake to conclude that Rummel's analysis of the nuclear arms race does not have important implications for those of us wrestling with similar issues today. Despite several predictions that missed their mark, Rummel's work sheds light on a number of fundamental scholarly debates, including those related to the nature of power in international politics, arms control, and nuclear deterrence. Moreover, many of his arguments seem evergreen in the light of a renewed Russian nuclear threat in contemporary Europe. Rummel's work, therefore, offers enduring lessons not only for international relations scholars, but also for policymakers attempting to minimize the enduring danger of nuclear annihilation.

\subsection{Rummel's Arguments}

Rummel identifies the logic of détente as stemming from two major assumptions. The first is that increased transactions between nations will result in greater harmony in their relations. Since cooperative transactions, such as trade, treaties, and conferences, tend to build trust, they establish a framework for nonviolent conflict resolution. Rummel calls this assumption Détente 1.

The second assumption, which Rummel calls Détente 2, is that we can reduce conflict between nations through arms control measures. Henry Kissinger described strategic arms reductions as 'the single most important component of our policy toward the Soviet Union' (Rummel, 1976: 24). According to Rummel, Kissinger viewed conflict as a product of the unbridled growth of national power and, therefore, Kissinger believed that limitations on military capabilities help states to cultivate peaceful relations and avoid war.

Rummel takes aim at both assumptions, beginning with Détente 1. From a theoretical standpoint, Rummel objects to the dichotomy between conflict and cooperation. A more apt bifurcation, Rummel argues, would be between isolation and interaction - conflict and cooperation being two different manifestations of the latter. Rummel offers the analogy of two individuals marooned on an island. The castaways can either (a) not interact or (b) combine efforts to find food and shelter. If they opt to do the latter, conflicts will naturally arise over any number of issuesfor example, the appropriate distribution of resources. Conflict serves to rebalance the power dynamic between the castaways, creating a new status quo in which cooperation is also possible. Rummel's point here is not that interaction will necessarily increase conflict, but that we should also not expect cooperation to necessarily engender peace.

The numbers, Rummel argues, bear out his conclusion. Dividing cooperation into four categories (cooperative transactions, student flows, joint membership in international organizations, and trade), and analyzing thousands of bilateral 
interactions between nations, including those between the United States and Soviet Union, Rummel finds cooperative interaction and conflict to be uncorrelated. He does find that conflict begets conflict. For example, he finds that military action and anti-foreign demonstrations are correlated. But insofar as the central premise of Détente 1 is concerned, cooperative transactions reduce neither the frequency nor the scope of inter-state conflict.

Rummel begins his critique of Détente 2, the notion that arms control reduces conflict, with an examination of the nature of power. Rummel observes that capability, or military strength, is 'often mistaken for power's essence' (Rummel, 1976: 49). A more holistic notion of power should incorporate two additional elements: interests, or national attention toward a goal, and credibility, which Rummel defines as collective will - a nation's ability to transform attention into action. Power is the sum of capability, interests, and credibility. If one of these three variables flags, power decreases, and if any of the variables is zero, a nation will be effectively impotent.

This leads to Rummel's criticism of Détente 2: proponents of détente dangerously conflate capability with power. Détente, Rummel writes, 'considers neither interests nor credibility, but focuses on military strength as the variable most related to conflict.' By attempting to lock in the US-Soviet balance of power through 'essentially equivalent' reductions in military capability, détente has the practical effect of unbalancing the bilateral relationship. This is because, according to Rummel, the Soviet Union has more invested in winning the Cold War; its geographical location and ideological commitments imbue it with greater resolve. Pointing to America's withdrawal from Vietnam, its removal of military bases from South Korea, and what he considered its self-sabotage in the nuclear arms race, Rummel paints a picture of a nation in retreat. Meanwhile, the USSR's invasion of Czechoslovakia, its infusion of aid to the North Vietnamese and the marxists in Angola, and its support to the Arab states during the Yom Kippur War, demonstrate its 'superordinate interest in defeating the West' (Rummel, 1976: 50). Because US nuclear superiority serves to offset the Soviet Union's advantages in terms of interest and credibility, arms control disproportionately harms the United States.

Rummel backs his assertions with statistical analysis, finding that '... neither parity nor superiority in military capability is associated with bilateral peace' (Rummel, 1976: 55). This seems to fit with Rummel's multifaceted understanding of power. So long as interest and credibility factor into the overall balance of power, quantitative evaluations of military capability will fail to tell the whole story.

After addressing the internal logic of détente, Rummel turns his attention to its practical effects. Rummel accuses Soviet leaders of engaging in bad faith, and American leaders of acting on blind faith. According to Rummel, while Washington views détente as a means of diffusing the security dilemma, Moscow sees it as 'a tactical policy change to permit the Soviet bloc to establish its superiority in the next 12-15 years' (Rummel, 1976: 29). This mismatch in expectations, therefore, puts the West in a position of unknowingly ceding global hegemony to the Communist bloc. 
Comparing a range of US and Soviet military indicators (and acknowledging that Soviet figures can only be estimated), Rummel calculates that far from maintaining 'essential equivalence', the détente-era arms control agreements ceded significant advantages to Moscow. He found that, from cruisers to cruise missiles, Moscow bested Washington on 40 out of 48 measures of military strength (see Fig. 6.1). Further, in the eight categories in which the United States led the USSR, it generally did so by a narrow margin, whereas the Soviet Union maintained robust

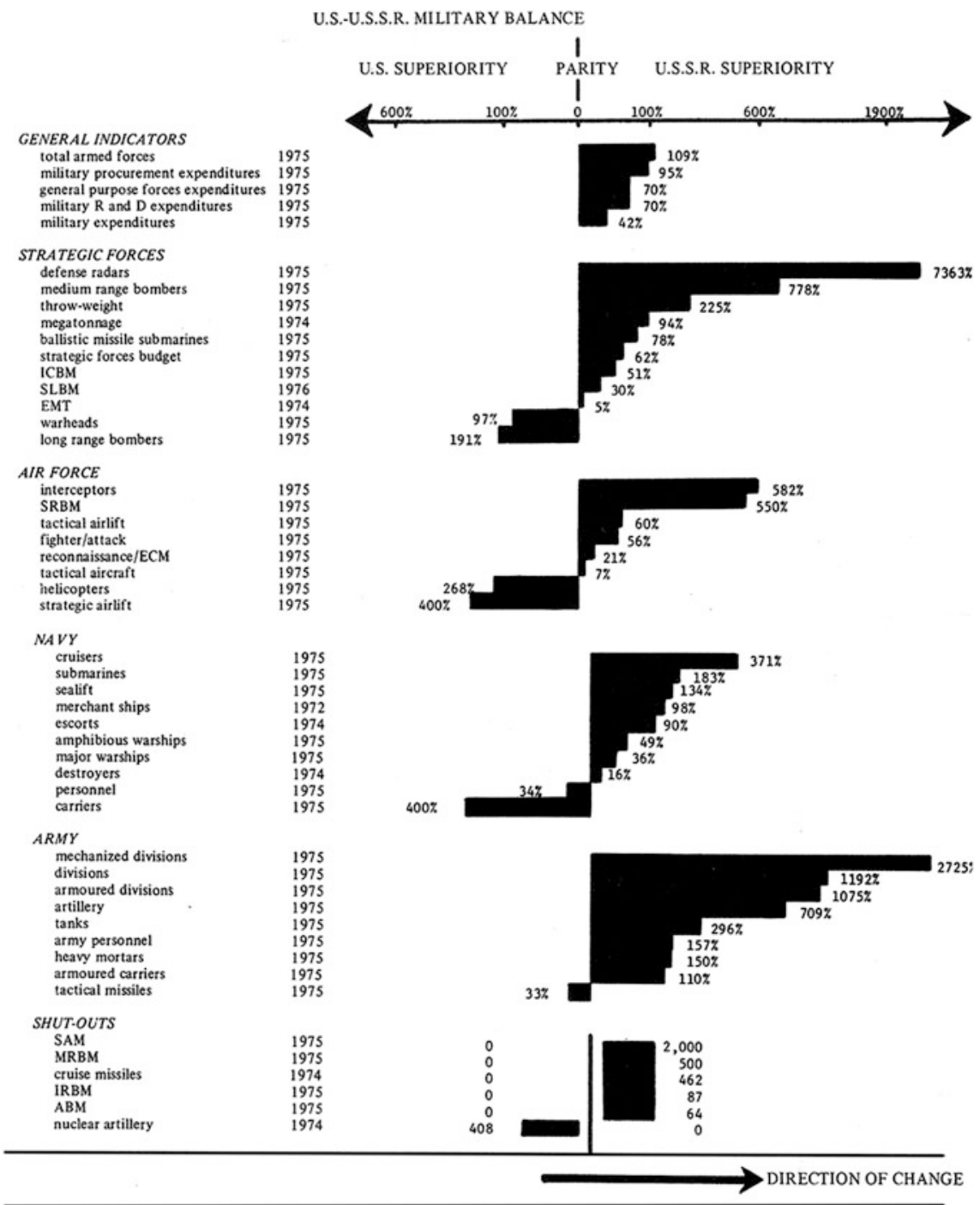

Fig. 6.1 Rummel's estimate of the US-USSR balance of military power. Source Rummel (1976: 60-61). Reprinted by permission of the publisher 
leads. 'The stark picture that emerges,' Rummel writes (1976: 133), 'is of an overall Soviet superiority that will continue to grow.'

Crucially, while the two sides arguably maintained a rough parity at the strategic nuclear level, Rummel saw America's capabilities along the spectrum of conflict as an invitation to war rather than a bulwark against it.

This is because, according to Rummel, nuclear deterrence rests on three pillars. First, each side must have sufficient strategic force to survive a surprise attack and retaliate with unacceptable damage on the attacker; neither side must be allowed to develop a first-strike capability. Second, each side must have adequate military power to meet diverse threats at all rungs of the nuclear escalation ladder, including tactical nuclear weapons. If there is a clear weakness for an opponent to exploit, this will encourage an attack and could force the actor with gaps in its capabilities to fall back on its strategic nuclear weapons. Third, each side must have robust conventional capabilities, which prevents them from resorting to nuclear options in the first place. If an actor can respond with conventional force, conflict might be contained. But if it must instead resort to tactical nuclear systems, this will make it easier for an exchange to escalate to the level of massive retaliation.

Rummel's view was that, under détente, the United States lost its conventional and tactical nuclear edge, and as a result was forced to rely too heavily on its strategic nuclear warheads. US weakness at the conventional and tactical nuclear level made it more likely that a conventional clash would snowball into all-out nuclear war. On the other hand, if Washington refrained from escalating to avoid this outcome, it would essentially cede victory to the USSR. Hence Rummel's central thesis: détente, by creating a power imbalance, forces an inevitable decision between American surrender and nuclear war. Furthermore, because Moscow recognizes Washington's dilemma, it may be motivated to initiate armed conflict in the first place.

In the final section of Peace Endangered, Rummel addresses the state of NATO's strategic nuclear arsenal. Given the Soviet drive toward military superiority, could it be possible for the USSR to one day gain strategic nuclear superiority, depriving the West of one of its few remaining advantages? Could this superiority grow to such an extent that the Soviets even achieve a first strike capability?

In answering this question, Rummel distinguishes between a preclusive first strike and a dominant one. A preclusive first strike deals only with the technical ability of the Soviet Union to completely destroy the American strategic arsenal, eliminating its retaliatory capacity. A dominant first strike focuses on a nation's will to retaliate. Rummel argued that even if the Soviets were technically unable to wipe out the US offensive strategic force, they might still achieve a dominant first strike if they could dissuade Washington from retaliating.

According to Rummel's calculations, the Soviets 'will soon have a preclusive first strike, if not by 1977 [one year after the book's publication], at least by 1981' (Rummel, 1976: 137).

Even if estimates of Soviet strategic capability are overblown, however, Rummel argues that the Soviets may already have achieved a dominant first strike. He asks 
the reader to imagine a surprise attack that takes out the majority of US land-based strategic forces, but leaves its sea-based forces and population centers intact. Moscow then issues an ultimatum: retaliate against our strategic forces, and we will destroy a city; retaliate against our population centers, and we will launch an attack that will kill roughly 100 million Americans. No matter how Washington responds, Moscow would be better positioned for any escalation. In such a scenario, Rummel argues, the choice would once again be between suicide and surrender - no choice at all. Rummel writes: 'Our weapons were meant to deter aggression. If deterrence fails, would a president still press the button? Of course not.' (Rummel, 1976: 141).

By pursuing a strategy built upon the shaky pillars of cooperation, disarmament, and misplaced empathy, Rummel concluded that American policymakers put the United States at a strategic disadvantage. He argued that détente must be abandoned, but objected to critics who claimed that this put the superpowers on a path to war. He writes,

Throughout history, peace has been maintained by clear purposes, military power, and the will to use it. ... When a nation's purposes become confused, its strength eroded, or its credibility questioned, aggression against it is encouraged, and is likely to occur (Rummel, 1976: 149).

According to Rummel, therefore, the solution is clear. The West must regain its military edge, demonstrate its willingness to use force, and reaffirm its commitment to winning the Cold War. In Rummel's view, it is military weakness, not military power, which is the principal cause of conflict.

\subsection{The Legacy of Peace Endangered}

Evaluating Peace Endangered is a challenging task. On the one hand, Rummel's prediction that the Soviet Union would achieve a first-strike capability, and that it might exploit this military imbalance to launch a nuclear sneak attack, never came to pass. Not only did the US emerge victorious from the Cold War, it did so despite a persistent nuclear deficit. By the conclusion of the Cold War in 1989, the Soviet Union's total nuclear stockpile outstripped that of the United States by some 13,000 warheads (Natural Resources Defense Council, 2006). Nevertheless, the internal weakness of the Soviet system and its disproportionate military spending placed the country on an unsustainable course - a fact that does not emerge in Rummel's analysis of national capability.

Rummel's criticism of Détente 1 is not without problems either. Even as the United States adopted a more confrontational stance under the Reagan administration, it continued to engage in cooperative interactions with the Soviet Union, including on major arms control initiatives like the INF treaty. Furthermore, and in direct contradiction to Rummel's claims, recent scholarship demonstrates that increased interaction does have a positive impact on peace. Research has consistently shown that countries with higher levels of membership in international organizations and greater levels of economic interdependence, for example, are less 
likely to experience militarized disputes (Oneal \& Russett, 1997). Rummel's findings likely diverge from those of other scholars because his analysis does not control for contiguity and geographic distance. Countries are more likely to go to war with their neighbors. Once that factor is taken into account, we find that increased economic interaction is associated with reduction in militarized conflict. Since Rummel's time it has become standard practice in modern analyses of liberal peace theory to control for contiguity and distance.

On the other hand, Rummel was right about much. The shift from détente to rollback under the Reagan administration - a new strategy that reflected many of Rummel's suggestions - did presage the end of the Cold War. During the 1980s, the United States engaged in a campaign of foreign interventions aimed not just at countering Soviet aggression, as in Afghanistan in 1979, but actively 'rolling back' communist and leftist governments. These interventions, including the invasion of Granada (1983), the bombing of Libya (1986), and the provision of arms and funds to the Contras in Nicaragua (1982), were designed to signal American intent and credibility. Meanwhile, Washington rebuilt its military forces, such that by 1986, it had surpassed the Soviet Union in terms of military expenditure (Noren, 2007). This campaign of defense spending, including reinstatement of the B-1 Lancer program, production of LGM-118 Peacekeeper missile, and investment in the Strategic Defense Initiative, eventually convinced the Soviet Union that it could no longer spend itself into exhaustion.

Did the United States win the Cold War because it followed a path similar to the one Rummel advocated or despite doing so? This chapter, of course, will not be able to resolve longstanding debates about the drivers of the Soviet Union's collapse, but it can evaluate the impact of the ideas contained in Peace Endangered for other issues in contemporary scholarship and policy. The rest of the article will, therefore, consider the implications of Rummel's views of power, arms control, and nuclear deterrence.

Rummel's definition of power as the product of a nation's capability, intent, and credibility is a nuanced take on an often-oversimplified concept. It is a formulation that casts light on seemingly inexplicable outcomes. Why, despite overwhelming advantages in terms of military technology, training, and manpower, did the United States falter in Vietnam (and the Soviet Union in Afghanistan)? Why was Adolf Hitler not deterred by British and French threats despite the overwhelming power of the alliance that they were able to bring together just a few years later? Why was Iran able to continue to enrich uranium despite demands from all five United Nations Security Council members that it suspend its program?

Rummel's formulation of power suggests an answer: many 'asymmetrical' conflicts are not asymmetrical at all. When intent, resolve, and credibility are taken into account, the seemingly weaker actor may even have the advantage.

This is a theme that has been picked up and extended by contemporary scholars. Arreguin-Toft (2005) has explained how the weak win wars. Press (2005) has argued that both power and interests must be taken into account in order to understand the credibility of military threats. And models of inter-state crises continue to focus on the interaction of resolve and capabilities (Fearon, 1995). For 
example, a recent comprehensive empirical examination by one of the authors of this article shows that, much as Rummel might have hypothesized, both the balance of resolve and the balance of nuclear forces are critical determinants of nuclear crisis outcomes (Kroenig, 2013).

It is precisely because of the multidimensional nature of power that arms control agreements so often break down, which Rummel believed would be inevitable. As his statistical analysis demonstrated, merely restraining a nation's military capability will not necessarily change its attitudes or manufacture goodwill from thin air; in fact, the causal effect often runs the opposite way. As Ronald Reagan was fond of saying about the US-Soviet relationship, 'We do not distrust each other because we are armed, we are armed because we distrust each other' (Reagan, 1985). In other words, arms races are often the product of conflicts of interest rather than the cause of them. By failing to recognize this dynamic, arms control regimes often do not address the root of the problem.

By the logic of Détente 2, for example, the ratification of the New START treaty in 2010 should have ushered in a period of reduced tensions between Washington and Moscow. Yet instead of a 'reset', we have seen in recent years a rapid deterioration in the relationship. The countries have engaged in policy clashes including Russia's invasion of Ukraine and threats to the rest of NATO. Russia has flouted its obligations under existing arms control regimes, testing a new intermediate-range, ground-launched cruise missile (GLCM) in direct violation of the 1987 INF treaty. Moreover, Russia's long-range RS-26 ballistic missile program can also be operated at intermediate range, allowing the country a technical circumvention of the agreement. These developments are part and parcel of a new and more assertive Russian foreign policy.

Some hoped that the rise of the Islamic State in Iraq and Syria (ISIS) would bring Washington and Moscow together through a common interest in battling Islamic extremism, but the interests here too are misaligned. While both would prefer to defeat ISIS, they have fundamentally different preferences for how best to go about it. Russia's foremost goal is to prop up embattled Syrian dictator Bashar al Assad, while Washington believes that ISIS can only be defeated after Assad is ousted from power.

It is this clash of interests between Washington and Moscow that renders Russian policymakers resistant to arms control measures. Arms control is predicated in part upon the notion that bad relations arise from the uncertain haze of the security dilemma. By allowing nations to signal their benign intent in a controlled manner, arms control regimes seek to clear this haze. Yet, because the ongoing tension between Washington and Moscow stems from a misalignment of interests rather than a misunderstanding of them, arms control regimes like New START and INF merely address the symptoms, not the causes, of conflict.

Indeed, the risk of nuclear war between the United States and Russia might be higher now than at any time since the Cold War. To understand why, let us revisit Rummel's discussion of the necessary conditions for bilateral deterrence. According to Rummel, deterrence requires strength in conventional, tactical and strategic capabilities. A gap at any of these levels creates an opening for an 
opponent to exploit, encouraging aggression and making war more likely. It also makes conflict more likely to escalate when it does occur. If a defending nation has a missing rung in the escalation ladder, it may be forced to reach for a higher rung. In this way, a conventional war can evolve into a tactical nuclear one, and a limited nuclear exchange can spiral into strategic exchange.

This account of nuclear deterrence has direct implications for the US-Russian relationship today, for several reasons. First, Russia has undertaken a massive modernization of and reinvestment in its nuclear forces, including new long-range, nuclear-armed cruise missiles, submarine-launched ballistic missiles (SLBMs), and silo-based and road-mobile ICBMs. Second, Russia has moved nuclear weapons to the center of its national security strategy and military doctrine. In 2000, Russia revised its nuclear 'no first use' doctrine to allow for 'de-escalatory' nuclear strikes. While this language was excluded from Russia's most recent public documents, the mentality of 'escalate to de-escalate' persists in Russian military circles and Russian officials have not shied away from issuing explicit nuclear threats (Kroenig, 2015a, b).

Moreover, even as Russia strengthens its nuclear capability and doctrine, the United States and NATO have moved in the opposite direction, deemphasizing nuclear weapons as a tool of statecraft. As it stands, NATO maintains a strong conventional force, a robust strategic nuclear capability and a significant gap in the middle, leaving Russia with a significant battlefield nuclear advantage. The tactical nuclear gap between Washington and Moscow, as Rummel would argue, encourages Russia's model of hybrid warfare, a combination of low-level aggression backstopped by threats of early nuclear escalation.

Moreover, US and NATO tactical deficiency puts it in a difficult situation should war break out. If the United States becomes embroiled in conflict in Ukraine or a NATO member country, and Russia opts for a limited nuclear strike, a US president would have few good options for a tailored, sub-strategic response. Under the current strategy in Europe, much as in Rummel's time, we in the West are 'seriously deteriorating our nuclear retaliatory capability while increasingly relying on an incredible massive retaliation threat' (Rummel, 1976: viii). A Russian tactical strike might very well then force a choice between 'war or surrender' (Rummel, 1976: ix).

The solution, Rummel would argue, would be for NATO to develop a more credible nuclear response option. Possibilities proposed by one of the authors of this article include placing lower-yield nuclear warheads on existing SLBMs and ICBMs, bringing back a sea-launched nuclear cruise missile, or rotationally basing B-52 bombers and nuclear air-launched cruise missiles in Europe (Kroenig, 2015a, b). By signaling US and NATO capability and credibility to Moscow, a strengthened nuclear capability could deter Russian aggression and help avert nuclear exchange.

Of course, for many, nuclear war remains an unthinkable prospect. But, as Rummel writes, 'From our contemporary viewpoint some aspects of the future always will be unthinkable.' The job of scholars and practitioners of national security is in part to anticipate and prepare for the kinds of scenarios that 'would not be accepted as a realistic novel' (Rummel, 1976: 17). The strength of Rummel's work lies in his willingness to engage with such ideas. 
Although Rummel's bold analysis caused him to ring some false alarms, it just as often led to conclusions that have stood the test of time. As the West faces a resurgent Russia and a new generation of scholars flocks to issues of nuclear deterrence and arms control, Rummel's A Peace Endangered continues to deserve a prominent place on our bookshelves.

\section{References}

Arreguin-Toft, Ivan (2005) How the Weak Win Wars: A Theory of Asymmetric Conflict. Cambridge: Cambridge University Press.

Fearon, James D (1995) Rationalist explanations of war. International Organization 49(3): 379-414.

Kroenig, Matthew (2013) Nuclear superiority and the balance of resolve: Explaining nuclear crisis outcomes. International Organization 67(1): 141-171.

Kroenig, Matthew (2015a) Facing reality: Getting NATO ready for a new cold war. Survival 57 (1): 49-70.

Kroenig, Matthew (2015b) Statement of Dr. Matthew Kroenig before Senate Armed Services Committee Hearing on 'Regional Nuclear Dynamics', http://www.armed-services.senate.gov/ hearings/15-02-25-regional-nuclear-dynamics.

Natural Resources Defense Council (2006) Global nuclear stockpiles,1945-2006, Bulletin of the Atomic Scientists 62(4): 64-66.

Noren, James (2007) CIA's Analysis of the Soviet economy. In: Gerald K Haines \& Robert E Leggett (eds) Watching the Bear: Essays on CIA's Analysis of the Soviet Union. Washington, DC: Center for the Study of Intelligence, http://www.cia.gov/library/center-for-the-study-of-intelligence/csipublications/books-and-monographs/watching-the-bear-essays-on-cias-analysis-of-the-sovietunion/article02.html.

Oneal, John R \& Bruce M Russett (1997) The classical liberals were right: Democracy, interdependence, and conflict, 1950-1985. International Studies Quarterly 41(2): 267-294

Press, Daryl G (2005) Calculating Credibility: How Leaders Assess Military Threats. Ithaca, NY: Cornell University Press.

Reagan, Ronald (1985) Address to the Nation on the Upcoming Soviet-United States Summit Meeting in Geneva, http://www.reagan.utexas.edu/archives/speeches/1985/111485d.htm.

Rummel, Rudolph J (1976) Peace Endangered: The Reality of Détente. London: Sage.

Open Access This chapter is licensed under the terms of the Creative Commons Attribution 4.0 International License (http://creativecommons.org/licenses/by/4.0/), which permits use, sharing, adaptation, distribution and reproduction in any medium or format, as long as you give appropriate credit to the original author(s) and the source, provide a link to the Creative Commons license and indicate if changes were made.

The images or other third party material in this chapter are included in the chapter's Creative Commons license, unless indicated otherwise in a credit line to the material. If material is not included in the chapter's Creative Commons license and your intended use is not permitted by statutory regulation or exceeds the permitted use, you will need to obtain permission directly from the copyright holder.

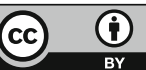

